\title{
Dealing with uncertainty: challenges and possibilities for the early childhood profession
}

\author{
MATHIAS URBAN
}

\author{
Martin-Luther-University Halle-Wittenberg, Germany
}

\begin{abstract}
SUMMARY: In many countries, strategies to further develop services and institutions for the education and care of young children are linked to a discourse on professionalism. Ambitious policy goals, it is argued, can only be achieved by a skilled and qualified workforce whose practice is guided by a professional body of knowledge. This paper argues that the prevailing conceptualisation of the early childhood professional is constructed out of a particular, hierarchical mode of producing and applying expert knowledge that is not necessarily appropriate to professional practice in the field of early childhood education. However, it is highly effective and contributes to forming a professional habitus that contradicts the relational core of early childhood practice. Drawing on the conceptual framework of hermeneutics, the article explores an alternative paradigm of a relational, systemic professionalism that embraces openness and uncertainty, and encourages co-construction of professional knowledges and practices. Research, in this frame of thinking, is understood as a dialogic activity of asking critical questions and creating understandings across differences, rather than producing evidence to direct practice.
\end{abstract}

RÉSUMÉ:

ZUSAMMENFASSUNG: In vielen Ländern werden derzeit Strategien zu Ausbau und Weiterentwicklung der Institutionen und Angebote für die Bildung, Betreuung und Erziehung junger Kinder mit einem Diskurs zur Professionalität in diesem Feld verknüpft. Die anspruchsvollen politischen Ziele können nur verwirklicht werden, so die Argumentation, mithilfe gut ausgebildeter und qualifizierter Fachkräfte, deren Praxis von einer professionellen Wissensbasis geleitet wird. In diesem Beitrag wird argumentiert, dass vorherrschende Konzeptualisierungen des professionellen Frühpädagogen aus einem besonderen, hierarchischen Modus der Erzeugung und Anwendung von Expertenwissen heraus konstruiert sind; einem Modus der dem professionellen Handeln im Feld nicht notwendigerweise angemessen ist. Ungeachtet dessen ist er höchst wirksam und trägt zur Herausbildung eines professionellen Habitus bei, der im Widerspruch zu dem auf wechselseitigen Beziehungen aufgebauten Kern frühpädagogischer Praxis steht. Ausgehend von einem hermeneutischen Denkansatz erörtert der Beitrag ein alternatives Paradigma einer systemischen Professionalität, die Offenheit und Unsicherheit begrüßt, ernst nimmt und zur Ko-Konstruktion von professionellem Wissen und Praktiken ermutigt. Forschung wird in diesem Denkansatz als dialogische Praxis und als zentrales Merkmal einer systemischen Professionalität verstanden. Sie ermöglicht, kritische Fragen zu bearbeiten und trägt dazu bei, Verstehen über Differenz zu erzeugen, statt Faktenwissen für die Anwendung in der Praxis.

RESUMEN: En muchos países, las estrategias para continuar desarrollando los servicios e instituciones para la educación y el cuidado de los niños menores, están enlazadas con un discurso sobre profesionalismo. Metas políticas ambiciosas, se argumenta, pueden ser logradas solamente por una fuerza de trabajo hábil y calificada, cuya práctica es guiada por un cuerpo de conocimiento profesional. Este articulo argumenta que la conceptualizacion prevaleciente de la profesionalización pre-escolar esta construida por un modo particular y jerárquico de producir y aplicar conocimientos de expertos, que no es necesariamente apropiada a las practicas profesionales del campo de la educación pre-escolar. En todo caso, esta es altamente efectiva y contribuye a formar hábitos que contradicen el corazón relacional de la práctica pre-escolar. Basado en un marco de referencia de hermenéutico, el artículo explora un paradigma alternativo, de un profesionalismo relacional y sistémico que abarca la actitud abierta y la incertidumbre, y que fomenta la co-construcción del conocimiento y de las prácticas profesionales. La investigación, en este marco de pensamiento, es entendida como una actividad dialogica de hacer preguntas criticas y crear comprensiones entre diferencias, más que de producir evidencias directas para la práctica.

Keywords: Professionalism, professional habitus, knowledge, evidence based practice, hermeneutics, critical thinking.

Introduction: Professionalism: a new paradigm in early childhood?

To begin with, you will be relieved to know that I am not going to tell you what to do.

(Winnicott, 1987, p. 15)

The famous introduction to D.W. Winnicott's classic The child, the family and the outside world appears to be perfect for any attempt to approach the contradictory debates on the early years profession that have gained new prominence in many countries in recent years. Albeit explicitly addressed at non-professionals - Winnicott writes about a young mother's experience of giving birth to a 
child - it covers the whole dilemma of adults working in the societal institution set up to educate and care for young children. The dilemma unfolds between the day-to-day experience of having to act concretely, spontaneously and autonomously in ever changing, uncertain situations which, to a large extent, are determined by factors beyond the practitioners' control, and the pressure that arises from increasing socio-cultural and socio-economic expectations to produce predetermined outcomes in this complex work context.

Along with an increasing division of labour, modern societies, over the past two centuries, tend to successively extend the responsibility for the upbringing of young children from the family domain to public institutions. Care and early education, which once used to be common social practice, have become specialised tasks for those who are specifically identified as early years practitioners: pre-school teachers, childcare workers, pedagogues, to name only a few. Roles, work contexts, levels of formal qualification, remuneration etc. of the early years practitioners always varied widely in different institutions or 'services', and in different periods of time. In this paper I want to explore a phenomenon that, in recent years, appears to have become inseparable from the numerous attempts to further develop the provision of early childhood education and care, nationally as well as in an increasingly globalised discourse: It is the unprecedented way in which both scholarly discourse and policy documents are referring to the early years workforce as something that has to be professionalised that provides the starting point for my argument.

Over the past decade, many countries have set ambitious policy goals to increase both quantity and quality of provision. The political agendas are driven by common concerns about employment, competitiveness and gender equality. As the OECD points out in the recent report on ECEC policies in twenty participating countries, factors for turning governments' attention to institutions and services for young children are obvious. They include:

The wish to increase women's labour market participation; to reconcile work and family responsibilities on a basis more equitable for women; to confront the demographic challenges faced by OECD countries (in particular falling fertility rates and the general ageing of populations, and the need to address issues of child poverty and educational disadvantage.

(OECD, 2006, p. 12)

It is in this economical and political climate, that, for instance, the European Union expresses the need to increase the numbers of childcare places and, at the Barcelona summit in 2002, agreed on providing fully subsidised childcare places for $33 \%$ of children aged $0-3$ and $90 \%$ of children from 3 to mandatory school age by 2010. According to OECD figures (2006, p. 78), only five countries ${ }^{1}$ had reached these goals by 2006 , but "several" others are described as being on the way to achieving similar coverage.

The main concern, at least from the perspective of governments of countries we regularly refer to as being "developed", is that "economic prosperity depends on mainstreaming a high employment/population ratio" (ibid), and policies to bring more women into the workforce have been put in place in most OECD countries. It is questionable, however, whether it is legitimate to speak about services for children when the driving factors for investing in them are so clearly economic in the first place.

From a pragmatic point of view, one could argue, anything that helps placing early childhood high on governments' agendas should be welcome. But there is another side to the coin of the economic rationale that gets out of sight too often: policies to increase female labour market participation, introduced in times of economic growth, are at risk of being abolished as soon as the economy faces a deceleration or decline. Not only are they unsustainable - they are also a highly effective means of governing, that is controlling women's, men's and children's participation in the society on the whole: Fundamental rights to participation in a democratic society are in effect, then, granted or denied according to the rationales of an increasingly globalised economy that lack any democratic legitimacy.

But there are other rationales, too, that have moved early childhood institutions onto policy agendas, as well as onto electoral agendas, as the OECD report points out. Besides being a condition for gender equality in an economy-dominated society, the expansion of early childhood institutions is seen as crucial for educational attainment, as the fundament for lifelong learning and social inclusion and equity. Concurrently, the policy context includes a new international and national attention to children's rights and participation framed by the UN Convention on the Rights of the Child and recognised explicitly in the Charter of Fundamental Rights of the European Union.

The policy commitment to ECEC provision at European level is also combined with a recognition that the provision has to be of good quality. There have been important European and national discussions on what quality entails, including the publication in 1996 of "Quality Targets in Services for Young Children" by the European Commission Network on Childcare and other Measures to Reconcile Employment and Family Responsibilities (1996). The title of the network notwithstanding - it fits seamlessly into the general socio-economic argumentative framework predominant in the late 1990ies - the "Quality Targets" are an important document as they offer a multi-dimensional framework for quality, including, among others, targets for policy, investment, participation and professionalisation. Furthermore, the acknowledgement of a socio-economic necessity for early childhood provision may have paved the way for the general acknowledgement, today, that more and better services require substantial investment.

National policy developments reflect the European and international debate. Many European countries have introduced national policies on "quality" in early childhood education and care in the past decade. In 2004, through a "Quality Decree" for example, Flanders introduced a participative evaluation system in which "quality" is seen as an ongoing construction, jointly determined by parents, staff, children and management (Peeters, 2005; Urban, 2006). The "National Quality Initiative" in Germany also pursued a systemic approach to "quality", developing, for the first time after the re-unification, quality standards and evaluation procedures for an early childhood sector that is characterised mainly by the principles of federalism (with the political and administrative responsibility for childcare and education lying at state (Länder) level and detached from the national government) and subsidiarity (which means that even though there is a public responsibility to ensure and plan for provision, the services are mainly provided by voluntary organisations) (Preissing, 2003; Urban, 2003, 2005b). Ireland, to give a third example, has been struggling to develop "quality" in a highly fragmented, diverse and under financed childcare sector (Murray, 2006; OECD, 2004, 2006, p. 353). Following intensive consultations with various stakeholders, Síolta, the National Framework for Quality has been launched in 2006. The document aims at supporting "individual professional practice and development"; it provides a "tool for management, strategic planning and policy development" as well as "a common base for the interactions of a varied team of professionals" (Centre for Early Childhood Development and Education, 2006).

\footnotetext{
${ }^{1}$ Belgium (Flanders), Denmark, France, Norway and Sweden.
} 
It is necessary to keep in mind that the concept of "quality" itself is highly problematic. It has been widely challenged by authors for its implicit relatedness to notions of universality, technocratic manageability and measurability (Dahlberg, Moss, \& Pence, 1999; Dahlberg, Moss, \& Pence, 2007; Pence \& Moss, 1994; Urban, 2003, 2005b). Too often, the language of "quality" is employed to legitimise the proliferating maze of regulations in early childhood education and care, and to undermine instead of support professional autonomy. We should, therefore, be cautious not to lose the "shared unease" with the terminology and the implications of this technical and managerial concept, as Dahlberg, Moss and Pence remind us (2007, p. 3). Quality remains a questionable concept, a problem that needs to be explored rather than to be taken for granted or to be presented as the solution. While we need to be critical about "quality" and its implications for practice, in a broader policy context, arguing for "better quality" can be an effective driving force.

What interests me in the context of this paper is the way the discourses on "quality" and "professionalism" seem to merge without difficulty at first sight. It seems to be generally recognised, today, that the workforce is central for achieving the ambitious policy goals of increasing both quantity and quality of provision. Recent research supports this notion (Dalli, 2003, 2005; Mac Naughton, 2005; Oberhuemer, 2005; Siraj-Blatchford, Sylva, \& Muttock, 2002) and along with policies to increase "quality", many countries have been introducing policies that aim at "professionalising" the workforce in recent years. In England, for example, the extensive Every Child Matters strategy (Department for Education and Skills, 2004) links explicitly to a Children's Workforce Strategy (Department for Education and Skills, 2005) that aims at building a "world-class workforce for children and young people" (ibid). The message is clear: Early Childhood practitioners need to be "qualified", "trained" and "skilled" in order to achieve the highly ambitious "outcomes" of Every Child Matters. Moreover, the strategy aimed at, and resulted in re-defining the workforce on the whole. The new formal status of "Early Years Professional" has been established, thus introducing - and, as some authors write imposing the notion of professionalism to the early years workforce (cf. the contributions of Gill McGillivray and Linda Miller in this volume).

Like England, other countries, today, are facing major workforce challenges. In many countries the workforce is split between early childhood teachers and childcare workers, reflecting a deep institutional divide between early childhood education and care that - at the same time - is increasingly questioned by practitioners, researchers and policy makers alike. The work itself is also recognised to be changing and increasingly demanding, because of increasing diversity among children and families and the complexity of the work in the institutions set up to serve them (OECD, 2001, 2006; Woodhead, 1996). Early childhood practitioners have to address not only the need to provide care, but also broader requirements - educational, social and cultural - e.g. collaborating with parents from diverse backgrounds and with diverse local communities.

While the work contexts are challenging and changing, and practitioners are increasingly expected to "act professionally" within these contexts, the terminology itself remains obscure. Carmen Dalli (2003), analysing the wording of job advertisements in New Zealand, reports that employers are either expecting applicants to join an existing team of professionals or are looking for people with a professional attitude. Kate Adams, in her contribution to this volume, explores understandings of professionalism in one European country (Scotland), only to find as many as eleven job titles for practitioners working with young children. Admittedly, the two studies reflect the situation in New Zealand and Scotland, respectively. From an outside perspective, however, both findings contribute to a broad picture that is identifiable in individual countries as well as in the international discourse: Increasingly high expectations (to act professionally!) have to be met by individual practitioners, while the structures wherein this professional practice takes place remain fragmented. Oberhuemer and Ulich (1997) have pointed out that there is no consensus on the role of practitioners working with young children. Ten years on, despite an unprecedented attention for early childhood education and care in the public debate, the picture has not changed significantly. Or has it?

D.W. Winnicott talks about the young mother's relief of not being told what to do. Even though she may prefer to "avoid thinking things out" $(1987$, p. 17), as long as there is love, the baby will probably get a good start. Early childhood practitioners, in their contradictory professional context, cannot feel this relief. In work contexts where they are expected not only to give children "a good start" but to achieve predetermined, assessable outcomes, practitioners are increasingly being told what to do, what works and what counts. And they are subject to a powerful strategy to bring forward a particular view of professional practice - which needs to be questioned, as I want to argue in the following sections.

\section{Talking the talk: dominant discourses and regimes of truths?}

Traditionally, conceptualisations of "profession" have always been linked to "knowledge". Whatever the actual practice in a given profession, it is embedded in a system of knowledge production and application that distinguishes professional practice from other forms of production of goods or services in any society. Most influential for developing this notion of "profession" as a particular organisational form in modern societies - that are structurally differentiated to a large extent - was the US-American sociologist Talcott Parsons (1902-1979). Parsons' work aimed at developing a generalised, abstract concept for describing what he called "The Social System" (1951). Parsons elaborated his general theoretical framework of "structural-functionalism" by exploring its relevance to various sub-systems of modern society, including the professions (Parsons, 1968). Even though Parsons' theoretical work has been criticised widely by sociologists for its implicit social determinism and conservatism, his explanation of a profession as a societal sub-system is still effective to date. Key features of the professional system - the ones you find in dictionaries of sociology, for instance - include a central regulatory body (to ensure the quality of performance of the individual professional), a professional code of conduct and an effective means of producing and managing the professional body of knowledge. Another central characteristic of the professional system, according to this perspective, is the existence of an effective control of entrance, regulating, for instance, numbers, selection and training of future professionals.

Sociological literature on professionalism abounds, and from the 1970ies, a stark critique of the roles and agendas of professions - in general - emerges. Referring to Marx and Gramsci, for example, Professionalism is seen as an effective means of a particular "intellectual class" to gain influence and power, and to secure social status and economic advantage in a structurally unequal society:

Professionalization is thus an attempt to translate one order of scarce resources - special knowledge and skills - into another - social and economic rewards. To maintain scarcity implies a tendency to monopoly: monopoly of expertise in the market, monopoly of status in a system of stratification. 
(Larson, 1977, p. vxii)

Again, knowledge, and the modes of its production, distribution and application, plays a central role in this game of power. But as sociologists tend to take more general approaches to the phenomenon of professionalism, one could also question to what extent this generalisation provides an adequate ground for exploring the characteristics of professionalism in early childhood - which is the intention of this analysis. I want to argue that what is presented to us as being general about professionalism in early childhood policy documents, regulatory frameworks, curricula etc. can also be seen as manifestation of a particular discourse: a very specific way of talking about professionalism that is neither neutral nor necessarily appropriate for the field of early childhood education and care (see also Dalli in this volume). It is, on the contrary, an effective means of control and regulation of diverse individual practice through dominant knowledge - something that has been described by Michel Foucault as "regime of truths". The way we talk about practice (or the way it is talked and written about by those whose voices are heard and considered as relevant) does not merely give an explanation of what is going on. It is an active agent instead. Discourses, writes Foucault, are "[...] practices that systematically form the objects [and subjects] of which they speak." (Foucault, 1972, p. 49).

Going back to the starting point of this argument - the unprecedented attention for early childhood, its institutions and, in consequence, in its workforce in national and international politics -, what stands out through the influential documents is the clear distinction between those who talk and those who are talked about. ${ }^{2}$ Early childhood education and care, as societal sub-system as well as a professional system is highly stratified. The gap between the Education Committee of the Organisation for Economic CoOperation and Development and a childcare worker or early childhood teacher is considerable. Consultations, held at national level by government departments who are introducing new policies, hardly ever reach the individual practitioner who is supposed to be working towards realising the policies. But stratification and distinction is not limited to relationships with "external" agencies, like international organisations and government departments. It is clearly visible within the professional system itself. Scholarly discussions about what it means and entails to be "professional" in early childhood often express expectations towards the individual practitioner, but seldom acknowledge the inequities of the knowledge producing and processing structures within the system that are highly effective as tools of regulation and self-regulation.

The epistemological hierarchy in our field consists of distinct layers, where the professional body of knowledge is produced (academic research, scholarly debate), transferred (professional preparation, pre- and in-service training) and applied (practice). There is a powerful top-down stream of knowledge presented as relevant for practice, and a similar downstream of expectations and advice about what needs to done at the practice levels of the hierarchy. Not only does this layout of the early childhood professional system constantly increase the pressure on practitioners, who, finding themselves at the bottom of the epistemological hierarchy, have to meet these expectations imposed on them. It also contributes to constructing and reinforcing a particular dichotomy in the field: There is, this perspective suggests, a clear distinction between theory and practice. And this theory/practice dichotomy links well with a structural-functionalist framework, where a social "problem" - and the way it is defined - is distinct from its "solution". The role of the "professionals", in this framework, is to contribute to "solving" a given problem by applying their specific knowledge, which they have acquired through formalised training.

A good example for the prevalence of the structural-functionalist conceptualisation of professionalism is the Every Child Matters programme in England, and the way it links to the Children's Workforce Strategy (Department for Education and Skills, 2004, 2006). The programme clearly defines the social problem (structural inequality and disadvantage that is putting increasing numbers of children and families 'at risk', drastically illustrated by the neglect, abuse and eventual killing of Victoria Climbié). It provides a clear set of goals that are presented as assessable outcomes (every child to be healthy, safe, enjoying and achieving, making positive contributions, achieving economic well-being). The related Workforce Strategy is explicit about how the outcomes can be achieved:

To ensure that children and young people achieve the five Every Child Matters outcomes, it is vital to have a children's workforce that is skilled, well-led and supported by effective, shared systems and processes.

(Department for Children Schools and Families, 2007)

The strategy then goes on defining the mode in which a body of knowledge is produced and managed, applied and, finally, used as means of entry-control for those wishing to join the profession as it "[...] sets out action to be taken nationally and locally to ensure that there are the skills, ways of working and capacity to deliver change for children" (ibid).

The "skills" necessary to "deliver" are drawn from a "Common Core of Skills and Knowledge" that are "needed" to work "effectively" (ibid). Everyone working with children, then, is expected by an anonymous "we" to demonstrate their competences in the areas defined by the Common Core, which is also presented as the future foundation for qualification, training and development of the workforce (ibid).

My intention here is certainly not to point a priggish finger at the English example. There are a multitude of similar examples to be found in policies and strategic documents in many countries, including my own ${ }^{3}$. Far from being unique, with respect to this analysis of professional systems, the Workforce Strategy represents a highly effective discourse, "that systematically form[s] the objects [and subjects] of which [it] speak[s]" (Foucault, 1972, p. 49).

The mechanisms of "professional" knowledge production, distribution and application that are implicit in these examples link to a wider predominant discourse on children and childhood in modern society, which, increasingly, is concerned about gaining certainties through regulation and achieving predetermined goals. It contributes to constructing a particular understanding of early childhood institutions as "sites for technical practice, seeking the best methods and procedures to delivering predetermined outcomes" (Dahlberg \& Moss, 2005, p. 2). This science-led search for problem-solving methods is built on two basic (and taken for granted) assumptions:

\footnotetext{
${ }^{2}$ This distinction clearly shows in historical as well as in recent debates on early childhood, as Gill McGillivray demonstrates in her contribution to this volume.

${ }^{3}$ In Germany, for example, Early Childhood curricula have been introduced at state level in recent years only. Some of them represent clear examples of the phenomenon discussed above: educational underachievement of groups of children growing up under precarious conditions is identified as "problem" which is to be "solved" through application of effective methodology provided by "science", and applied by "skilled" practitioners.
} 
[...] a stable, defined and transmittable body of knowledge, but also implicitly a particular subject, today the autonomous and flexible child. The defining question for this possibility is 'What works?': which technical practices will most effectively ensure the desired outcomes?

(ibid) ${ }^{4}$

There are, in consequence, obvious professional tasks arising from this Parsonian problem-setting / problem-solving mindset, in which scientific knowledge, as Dahlberg and Moss argue, provides the main means for achieving order:

We know the adult we want the child to become, we know the world in which the adult must live and work. The challenge is to produce the adult to fit into that world, in the most cost-effective way - and with the help of scientific knowledge-asregulation the challenge can be met.

(Dahlberg \& Moss, 2005, p. 6)

Dominant discourses that furtively turn into means of regulation, or regimes of truths, hide under different veils. Discussing conceptualisations of professionalism in early childhood, "evidence-based practice" is one of them. It is nurtured by an increasingly influential critique of educational practices in general, which are accused to be "failing" largely because they are not informed by educational "research knowledge". 5 Considerable efforts are being taken in many countries and internationally (and considerable amounts of money spent), to promote the idea of education as an evidence-based practice and of teaching as an evidence-based profession (Biesta, 2007). Supposedly aiming at narrowing the gap between research, policy and practice, Biesta argues, the prevalence of the concept of "evidence-based practice" leads, on the contrary, to an increasing tension between scientific and democratic control over research as well as practice:

On the research side, evidence-based education seems to favour a technocratic model in which it is assumed that the only relevant research questions are questions about the effectiveness of educational means and techniques, forgetting, among other things, that what counts as 'effective' crucially depends on judgements about what is educationally desirable. (Biesta, 2007, p. 5)

For educational practitioners, working in an environment where "effectiveness" is defined externally, and where the decisions about what desirable outcomes should be have already been made, then, it is almost impossible to make these judgements themselves in a way that is relevant for their actual working context (i.e. the particular children, families and communities they are working with). Evidence-based practice, as something derived from educational science as means of knowledge production, and to be implemented, disqualifies practitioners and deprives them of their professional autonomy. Moreover, it actively hinders a practice that is constantly developed by asking critical questions:

The focus on 'what works' makes it difficult, if not impossible to ask the questions of what it should work for and who should have a say in determining the latter.

(ibid)

"Evidence-based practice", and the framework of professional epistemology it implies, is by no means as neutral as it may appear. Judgements and values lie at the very core of the concept, but, in a powerful shift, the processes of judging, valuing and contextual meaning-making are steered away from practitioners. But it is another implication of this concept that brings it even closer to the questions I am pursuing in this inquiry. Evidence-based practice is embedded in a very specific paradigm that Oliver and Conole (p. 388) summarise as follows:

At the heart of evidence-based practice lies a concern for the effectiveness and the best way of researching this, it has been argued, is by means of experimentation [...] The form of experimentation that has found particular favour within evidencebased practice is the randomised control trial. This is privileged on the basis of a search for causality [...] Indeed, this method has become all but synonymous with evidence-based practice, having been used to define in American law what counts as "rigorous" research and how evidence-based practice should be implemented.

This, as Biesta argues, produces a notion of professional practice as intervention, which, in fact, is a causal model of professional practice. The basic assumption of this model is that professionals act - or intervene - in a particular situation in order to bring about certain effects that can be determined beforehand. There is, it is suggested, a secure relation between the intervention and its outcomes (Biesta, 2007, p. 7). But what if, for some reason, the desired effect does not show?

Even if it is reasonable to say that substantial investment in early childhood services and programmes does make a difference, it is unlikely that each individual child will be of better health, achieving better at compulsory school and enjoying economic-wellbeing as a result of these programmes. My argument here is that the powerful conceptualisation of the early childhood professional in a paradigm of clearly defined problems, predetermined outcomes and evidence-based, hence "right" practices implies failure without acknowledging that "failure", or the uncertainty about what the outcomes of the interaction with a child in a complex situation will be, lie at the very core of the early childhood profession.

This, in consequence, leaves early childhood practitioners with a fundamental dilemma: in order to achieve recognition, in public and in the domain they are working in, they have to construct and communicate their professional identity against the key characteristics of their practice. Reporting and commenting on their practice, and the difficulties they are facing in day-to-day

\footnotetext{
${ }^{4}$ For a detailed analysis of how even supposedly holistic and open frameworks can contribute to producing this particular neo-liberal version of the universal child, see Iris Duhn's excellent critique of Te Whāriki, the New Zealand early childhood curriculum (Duhn, 2006).

${ }^{5}$ For an extended critique of this particular paradigm, in which research knowledge is comprised of a scientific "grasp of the object", see Schwandt (2004) and Taylor (2002).
} 
interactions with children and families, practitioners clearly express this dilemma. Data from recent and ongoing research suggest that practitioners are increasingly moving from a simplistic and technical, to a relational and therefore uncertain perception of their practice. At the same time they seek, sometimes desperately, to avoid uncertainty, mistakes and "failure" - constructing themselves, in their responses to studies, in conversations with parents or in the public sphere as "experts" who know what to do and who are being told what to do by a knowledge producing system that guides their practice. ${ }^{6}$

Discourses form the subjects of which they speak and, in early childhood, contribute to constructions of professional identity (cf. McGillivray in this volume). They do so to the extent that the factors that shape perceptions and behaviour are too often not perceived as being external at all. They become internalised and form what could be called, following Pierre Bourdieu (1977) a particular "professional habitus"?

\section{Walking the walk: Professionalism in early childhood as a relational concept}

The reason life is so strange is that we have simply no idea what is around the next corner, something most of us have learned to forget.

(Colum McCann: Zoli)

The problem with this professional habitus, shaped by a particular way of knowing how we know what we know (professional epistemology) is that, quite often, it contradicts day-to-day experiences of early childhood practitioners. First of all: Early childhood education is a messy business. Its "practice" unfolds in interactions between children and adults, individuals and groups, families and communities, laypersons and "professionals" - all pursuing their own and often contradictory interests. These relationships are all but static. Even though we pretend to be in control, and we invent all sorts of implements to formalise the interactions (e.g. settings, classes, morning sessions, circle time, parent-teacher meetings, distinct "free play" sessions etc.), they constantly shift and re-arrange in unpredictable patterns. ${ }^{8}$ Moreover, they are by no means made of one-way communications but are always reciprocal. Situations and "problems" that early childhood practitioners are dealing with on a day-to-day basis are highly complex (see also Dalli and Cherrington, forthcoming). Think of the young mother who, smelling of alcohol (again!), is handing over her child, who apparently has a temperature, on a Monday morning. A situation that is not unusual to early childhood practitioners. But what are the factors that "determine" this situation? What is "the problem"? Is it the mother's addiction, the family's living conditions in a "disadvantaged" neighbourhood, the child's illness and the centre's health and safety policy, the child's need of positive experiences given the irresponsibility of the mother? Most likely, it is a tangle of all of them, and of a hundred other things that would come to mind if we would dwell on this example.

What is characteristic of these complex situations, that are so common in early childhood practice, is that they elude any simplistic problem-solving-through-application-of-knowledge mechanism. Even the most common situations in early childhood practice do not present themselves as clearly distinguishable problems, or simple tasks that imply one particular action towards their "solution". Instead, practitioners find themselves challenged by the problem of "setting the problem", which, according to Donald Schön (1983), is an activity of meaning making that involves value-based decisions and experience, and which cannot be dealt with by "applying" standard theories and techniques:

In real-world practice, problems do not present themselves to the practitioner as givens. They must be constructed from the materials of problem situations which are puzzling, troubling, and uncertain. In order to convert a problematic situation to a problem, a practitioner must do a certain kind of work. He must make sense of an uncertain situation that initially makes no sense.

(Schön, 1983, p. 40 emphasis added)

This activity of making sense of uncertain situations, then, takes place with the practitioner being part of the situation herself. The challenge is to get into a "reflective conversation" with the situation, thus re-framing it in order to both understand and change it. Practice itself, from this perspective, is a sphere where professional "knowledge" is produced - by practitioners who are in relationships with others (children!), and from questions arising from the situations they are involved in.

Whatever the results or "outcomes" of early childhood practice, they are clearly not due to the practitioner acting on a particular individual, or group. That is not to say there are no outcomes. But they inevitably emerge from interactions between the practitioner and the child, both embedded in complex socio-ecologic contexts. Early childhood practice is a constant co-construction - and therefore necessarily open and undeterminable. ${ }^{9}$

There are other reasons, beyond the immediate interaction between practitioner and child that contribute to the inevitable and necessary openness of early childhood practice. The social and cultural contexts of the relationships between children and adults that we usually refer to as education - has changed dramatically in modern societies. Exploring the changes in "Western" societies after World War II, and the "New Relationships between the Generations" that arose from these changes, Margaret Mead (1978)

\footnotetext{
${ }^{6} \mathrm{I}$ am referring to recent and ongoing studies, carried out in various contexts: Carmen Dalli's work on professional ethics and identities in New Zealand (Dalli, 2003); first findings of the international "Day in the Life of an Early Years Practitioner" project, presented at the 2007 annual conference of EECERA; "Bildung: elementar", a participatory curriculum development project in Germany (Urban, 2005a; Urban \& Murray, 2005) and an international study on "Strategies for Change" in ECEC systems (Urban, 2007).

${ }^{7}$ Bourdieu explains "habitus" as "lex insita"(immanent law) (1977, p. 81), a system of dispositions through which certain behaviour is considered "natural" among a community. These dispositions are constantly but unwittingly produced and reproduced by the members of the community: "[...] actions and works are the product of a modus operandi of which he [the member, M.U.] is not the producer and has no conscious mastery, they contain an 'objective intention' [...] which always outruns his conscious intentions." (p. 79)

${ }^{8}$ Besides early childhood education, there are other examples of systems whose dynamics are highly sensitive to their initial conditions but seem to develop in unpredictable ways. The so-called butterfly effect is one of them. In mathematics, the behaviour of these systems is referred to as deterministic chaos.

${ }^{9}$ Obviously, this can be said of any professional practice that constitutes in interactions with fellow human beings. There is a clear distinction, though, to technical practice, where a distinct action (e.g. pushing the 'right' button) produces a predictable result.
} 
introduced the concept of a cultural shift from what she called postfigurative to prefigurative ways of teaching and learning. While in postfigurative cultures, that are more or less static, adults' knowledge and experience can be "passed down" from the older generation, providing the younger with adequate equipment to master their lives, this is no longer the case in modern societies under conditions of change. We only need to look at the changes that occurred during our own lifetime (e.g. the rise of information technology, unprecedented global migration, the shaping of local living conditions through the effects of a globalised economy, etc.) to understand that today we don't know what to teach our children in order to enable them to cope with future challenges. In our prefigurative culture, adults' experiences and knowledge can no longer be projected linearly, to serve as a blueprint for our children's future. This has radically reversed educational relationships as in prefigurative cultures it is no longer the parent or the grandparent that represents what is to come - but the child, Mead explains $(1978$, p. 83). Adults, instead of leading children into a future that is by and large already known, now "are equally immigrants into the new era" (p. 70). ${ }^{10}$

The implicit conceptual shift from acquisition of knowledge to an active, co-constructivist making of experiences appears to be uncontested today - at least in our understandings of children's learning. We talk about children as "active learners", promote a "pedagogy of listening" and dialogue (Rinaldi, 2005, p. 57), and recent research emphasises that children's exploring and meaningmaking activities unfold their full potential only when they take place in meaningful, child-led interactions between children and adults; in activities Siraj-Blatchford and Sylva (2004, p. 720) refer to as "sustained shared thinking". When it comes to the implications for conceptualisations of the early childhood profession, the situation is contradictory, thus contributing to the practitioners' dilemma. As individuals (or team members), practitioners are living and acting a relational, reciprocal, open and inevitably uncertain professionalism, and they are increasingly expected to do so by those who dominate the discourse that subsequently manifests in qualification and workforce strategies. They are, at the same time, part of a professional system that, instead of being co-constructive, and all but embracing uncertainty, still largely operates within a paradigm of hierarchical knowledge production and application. Acting professionally under conditions of change, following Margaret Mead, would require new models instead:

Now, with our greater understanding of the process, we must cultivate the most flexible and complex part of the system the behaviour of adults. We must, in fact, teach ourselves how to alter adult behaviour so that we can give up postfigurative upbringing, with its tolerated cofigurative components, and discover prefigurative ways of teaching and learning that will keep the future open. We must create new models for adults who can teach their children not what to learn, but how to learn, not what they should be committed to but the value of commitment.

(Mead, 1978, p. 87)

The paradigmatic shift, however, remains yet to be achieved. The question is whether or not we can move on from questioning individual practices of practitioners to questioning practices at every layer of the early childhood professional system - and the system on the whole. The professional system, and its practices comprises individual and collective practices in any early childhood setting, as well as in training ${ }^{11}$ and professional development, in academia, in the administrative and political sphere, and in research in these contexts itself. Since all of these elements are embedded in - and contributing to - the wider social, historical, economic and political context of a society, with its local, national and increasingly global dimensions, they can be referred to as ecological. The challenge, then, is to promote a critical ecology of the profession, in early childhood and beyond, that is informed by the political and social realities that produce knowledges and practices, "together with the use of this knowledge to strategically transform education in socially progressive directions" (Mac Naughton, 2003, p. 3).

\section{A different paradigm: Professionalism in early childhood as an activity of creating understandings}

We have already seen that there are inherent tensions and contradictions between the way professional habitus is unwittingly shaped by a dominant discourse of knowledge, expertise, technology etc. and the key characteristics of professional practice in the field of early childhood. Explored from this perspective, the fundamental dilemma of the early childhood profession, today, is that practitioners are left in an impossible situation: they are expected to act professionally - within a professional system that is largely unprofessional, considering the key requirements of the field. It is hard to see, therefore, how a sustainable change in professional practice can be achieved without a radical change of the conceptualisation of the entire professional system. A key feature of this professional system, as we have seen, is the way knowledges and understandings of the subjects and objects of its practice are constructed.

But from a relational, i.e. critically ecological understanding of the early childhood profession, the prevailing concept of "research", conducted to produce "evidence" to direct the professional practice is no longer tenable.

Critical authors in the human and social sciences have been suggesting an alternative model of creating understanding that appears to be more suitable for complex interactions between "self-interpreting, meaning-making human beings" (Taylor, 1995). Rooted in the thinking of German philosopher Hans-Georg Gadamer $(1960,2004)$ and known as Hermeneutics, it places the way we are in the world (ontology) before the constitution of warranted knowledge (epistemology). Hermeneutics entails a different conception of the notions of research and knowledge, although its preference of being does not mean knowledge does not matter. But, as Schwandt (2004, p. 35) argues, "asking and answering questions about the nature of knowledge is not the way to begin modelling what is entailed in understanding human reality". My argument, here, is that the key to modelling an alternative paradigm for early childhood professionalism lies in the hermeneutic concept of understanding because it radically questions the hierarchy

\footnotetext{
${ }^{10}$ A notion that has been adopted, twenty years later, by Michel Vandenbroeck (1999, p. 30) as he writes about fostering children's identities in rapidly changing societies.

${ }^{11}$ I am using the term training reluctantly, and only because it is how education, preparation and continuous learning of early childhood practitioners are usually referred to. Training, as a particular concept of learning through instruction, repetitive practise etc. is about acquiring skills to apply and deliver technologies. Training is about being taught how to do things right. Its connotations contradict the very essence of professional and educational practice as a transformative practice of mutual dependence and respect, co-construction and shared meaning making between human beings.
} 
between those who produce knowledge-through-research and those who apply and deliver. In hermeneutic inquiry, knowledge is not brought forth by the intellectual or methodological activity of the researcher. Coming to an understanding, in contexts of human realities, is a dialogic process "in which one participates, not an activity over which one exercises methodological control" (Schwandt, 2004, p. 38). The way participants engage in the mutual activity of coming to an understanding of a situation resembles Donald Schön's description of practitioners that are constantly engaged in "reflective conversations with the situation". However, it adds a new dimension to it as it allows for the individual practitioner to become an actor in the system that generates professional knowledge.

Seeking to get involved in such a dialogue is a risky business for all participants - but mostly for researchers. Linked into a mutual (as opposed to an individual) process of meaning-making, researchers can no longer treat their informants as a generalised other, "seeking only to understand typical behaviour so that one can predict the other's behaviour in order to achieve one's own purposes. Nor can one simply claim a kind of special mystical union or empathy with others through which one presumes to understand others better than they understand themselves" (ibid). In a hermeneutic frame of thinking, the "other" in this dialogic encounter has to be acknowledged in his or her autonomy and for his genuine contribution to the emergence of an understanding. This, then, is no longer a question of choosing appropriate methodologies for research with (as opposed to on) practice but an ethical one as it requires making a choice and taking a stand: to being open to others and to respecting their autonomy, presuming, as Warnke (2002, p.93, as cited in Schwandt, 2004) explains, "they possess an independence and voice we must address and by which we ourselves are addressed."

The counterpart of this respect for the autonomous other is the recognition of the researcher's own ways of understanding and knowing (one's own hermeneutical situation, according to Gadamer) - and the historically and culturally conditioned biases that have shaped them. Gadamer (2004) argues it is impossible to gain understanding of any subject without first studying one's own tradition, and the prejudices which our position within that tradition has nurtured in us. An exercise that, once begun, will not only increase our awareness, but will enable us to gain new insights from our inquiries. Here lies, of course, another risk for the researcher's identity which has been nurtured in the safe haven of the knowledge production part of the system:

To listen to others different from ourselves we must remain open and that means parts of our interpretative forestructure is rendered at risk. Said differently, active listening requires personal vulnerability. Risking self-identity is dangerous.

(Garrison, 1996, p. 449)

The necessarily participatory project of creating understandings through systematically organising dialogues in which all participants equally talk and listen challenges the hegemony of expertise and dominant knowledge - but it also bridges the gap between the ways of being and the ways of knowing in a professional system. "Dialogue across differences" is possible - and it opens a perspective to overcome the inherent dilemma of the early childhood profession as it "embraces difference, diversity, and the messiness of human life rather than seeking, in the first instance, to resolve it" (Schwandt, 2004, p. 40).

Creating understandings through dialogue across differences, then, offers a real possibility to reconceptualise the mode knowledge and practice are developed in the professional system. In order to create change, in early childhood, the dialogic interactions between "researcher" and "practitioner" (a dichotomy that becomes obsolete) need to be contextualised. In other words, instead of being a purposeless bilateral conversation between the partners, they become systematic inquiries into, and explorations of possibilities for acting in complex, uncertain situations with children, families and communities in order to change them. Research, from this perspective is a practice itself - as much as "practice" is constant inquiry. A similar notion of "practice" as a purposeful dialogic relationship which can be organised systematically to create understandings as well as to create change, has guided the educational and political work of Paolo Freire throughout his life. He introduced the concept of dialogue in his early writings as core activity to overcome hierarchical relationships in education:

Through dialogue, the teacher-of-the-students and the student-of-the-teacher cease to exist and a new term emerges: teacher-student with students-teachers. The teacher is no longer merely the-one-who-teaches, but one who is himself taught in dialogue with the students, who in turn while being taught also teach. They become jointly responsible for a process in which all grow.

(Paulo Freire, 2000, p. 80, first published in 1970)

Re-visiting his beginnings in later writings, Freire (1997) emphasises the radical nature of the dialogic project in education and society. Far from being "a tool" for teaching, he explains, "dialogism" is a requirement of human nature and a sign of the educator's democratic stand (p. 93). Dialogic relationships also link acting and knowing reciprocally: they are, Freire writes, "a fundamental practice to human nature and to democracy on the one hand" but also "an epistemological requirement" (ibid). Systematic dialogue, as understood and practiced by Paolo Freire, could be seen as a way of knowing, inseparable from a way of being of the educational practitioner-researcher, grounded in the openness of education that Freire describes as its very nature:

One of the roots of education, which makes it specifically human, lies in the radicalness of an inconclusion that is perceived as such. The permanence of education lies in the constant character of search, perceived as necessary. Likewise, here lie also roots of the metaphysical foundation of hope. How would it be possible for a consciously inconclusive being to become immersed in a permanent search without hope? My hope starts from my nature as a project. For this reason I am hopeful, and not for pure stubbornness. (ibid)

\section{Towards systemic professionalism in early childhood: hopeful examples and an open framework instead of a conclusion}

In Ireland, the 'éist' diversity and equality in early childhood initiative is successfully involving early childhood practitioners in questioning their practices regarding the diversity of children and families in an increasingly unequal society. The project has created a space for practitioners' inquiries into their day-to-day practice; it encourages them to experiment and to reflect on their experiences 
(Murray \& O'Doherty, 2001). Raising awareness of own cultural prejudices and biases has been a starting point of the project's ongoing journey. Practitioners' voices and their experiences from this project are informing national and regional policies on diversity and equality (e.g. Office of the Minister for Children, 2006) and the project now engages in systematic professional development through a national network of "trainers". 'éist' has been and is a key member of a European network on "Diversity in Early Childhood Education and Training” (DECET), which offers a forum for practitioners, researchers and policy makers at international level.

In Germany, in 2003, practitioners together with a research team at the University of Halle-Wittenberg set out on a project to develop an early years curriculum, funded by the Department for Social Affairs of the state of Saxony-Anhalt. Designed as a participatory action research project, Bildung: elementar (Urban, Huhn, \& Schaaf, 2004) systematically offered a space for practitioners to develop and pursue their own research questions regarding children's learning and how to best support it. Starting from practitioners' experiences and "tacit knowledge", the questions that emerged in the process then framed a systemic critical reflection, involving practitioners, members of the academic research team and a wide range of actors in the field including parents. The curriculum document that was developed in this joint process consequently focuses on professional attitudes towards coconstructive pedagogy. Instead of listing early learning goals, it offers a framework of questions that support practitioners in observing and inspiring children's learning. The curriculum explicitly names the responsibilities of actors at all layers of the professional system, including those involved in research, continuous professional development and policy making. Bildung: elementar demonstrates how the knowledge-production-and-application model can be reversed and that professional knowledge can be successfully co-constructed. The curriculum has been made mandatory for all services for children from birth to compulsory school age in 2004; the Bildung: elementar project has since built a professional learning network involving practitioners in an increasing number of early childhood settings across the state (Bildung: elementar, 2007).

Funded by the Department of Education, the New Zealand Centres of Innovation initiative (Ministry of Education, 2007) provides resources and a secure framework for developing local responses to local requirements - which are then employed to inform changes of the EC system on the whole. Early childhood settings across the country are encouraged to apply for this initiative by illustrating practices they consider to be innovative and which they want to explore and further develop in a three-year action research process. The participatory action research is facilitated by a "research associate", typically a researcher from the university, who has to be identified by the centre. The initiative draws on the diversity of local experiences, the capability of practice to bring about innovation, and to contribute actively to building a professional body of knowledge. While policy provides a stable and well resourced framework for the local research and its dissemination, academic researchers take on the role of "critical friends" (Urban, 2007), working at eye level with practitioners and communities to pursue questions of relevance for the entire professional system.

Some cornerstones emerge from these vignettes - and from the multitude of other possible examples - for a professional system in early childhood that operates differently from prevailing mechanisms of knowledge production, distribution and application. First of all, there is shift of perspectives, as the focus moves from the individual practitioner (who has to be professionalised in order to apply and deliver) towards the reciprocal relationships between the various actors and their roles at different layers of the system: a complex ecology of the profession rather than a trivial machinery. Professionalism, then, can be understood as an attribute of the entire system, to be developed in its reciprocal relationships.

Secondly, a key feature of a professional system would be its ability to encourage and systematically create spaces for dialogue and for asking critical questions at every layer of the system - and to value the multitude and diversity of answers as key to creating new understandings. The challenge is to create a professional environment for constant inquiry - not only into individual practice; but for critical inquiry into the context and the preconditions for this practice, including the life situations of children and the cultural, historical, economic and political realities and inequalities that shape them. A professional system that unfolds around critical questions about the taken for granted preconditions and assumptions builds on Donald Schön's concept of the reflective practitioner - but it expands it to critical reflectiveness ${ }^{12}$, which, as a feature of the system rather than of the individuals within it, is a transformative practice in the tradition Freire's concept of conscientisation.

A third cornerstone of a professional system in early childhood education arises from Paolo Freire's notion of hope (as an ontological need, as he explains it). Educational practice is there for a purpose and it implies change. A professional system grounded on a Freirean concept of hope offers a perspective to address the direction of this change. The hoped-for has to be debated - and this directs the attention from the restricting question of what works towards questions of meaning, value and purpose. Encouraging and empowering actors at all layers of the system to engage in these processes of meaning-making and exploration of possible futures is necessary, as Freire (2004, p. 2) explains: "As an ontological need, hope needs practice in order to become historical concreteness. That is why there is no hope in sheer hopefulness. The hoped-for is not attained by dint of raw hoping. Just to hope is to hope in vain."

\section{References}

BIESTA, G. (2007). Why "What Works" Won't Work: Evidence-Based Practice and the Democratic Deficit in Educational Research. Educational Theory, 57(1), 1-22.

Bildung:elementar. (2007). Bildung:elementar. http://www.bildung-elementar.de/ (Accessed 01/28/2008)

BOURDIEU, P. (1977). Outline of a theory of practice. Cambridge: Cambridge University Press.

Centre for Early Childhood Development and Education. (2006). Síolta. http://www.siolta.ie/about.php (Accessed 01/03/2008)

DAHLBERG, G., \& MOSS, P. (2005). Ethics and Politics in Early Childhood Education. London; New York: Routledge Farmer

DAHLBERG, G., MOSS, P., \& PENCE, A. (1999). Beyond Quality in Early Childhood Education and Care. Postmodern Perspectives. London: Falmer.

\footnotetext{
${ }^{12}$ Glenda MacNaughton, in her 2005 book titled "Doing Foucault in Early Childhood Studies" explains that connecting the "critical" to reflection is about directing the attention away from the individual and towards "the operation and effects of power relationships between people." She describes critical reflection as "the process of questioning how power operates in the process of teaching and learning and then using that knowledge to transform oppressive or inequitable teaching and learning processes" (p. 7). Mac Naughton provides excellent examples of critical questions for early childhood practitioners (Mac Naughton, 2003). My concern is, though, that this concept of critical reflection can unintendedly carry a risk of individualising the responsibility for developing critically reflective practice, thus imposing an enormous pressure on the individual practitioner.
} 
DAHLBERG, G., MOSS, P., \& PENCE, A. R. (2007). Beyond quality in early childhood education and care: languages of evaluation (2nd ed.). New York, NY: Routledge.

DALLI, C. (2003). Professionalism in early childhood practice: thinking through the debates. Paper presented at the 13th annual conference of EECERA, 3-6 September 2003, University of Strathclyde, Glasgow.

DALLI, C. (2005). The New Zealand Story of EC Professionalisation. Paper presented at the International conference on Change Agents in Early Childhood Education and Care, EC+P. Early Childhood and Profession. International Centre for Research, Studies and Development. Martin-Luther-University Halle-Wittenberg.

Department for Children Schools and Families. (2007). Workforce Reform. $\mathrm{http} / /$ www.everychildmatters.gov.uk/deliveringservices/workforcereform/ (Accessed 01/10/08)

Department for Education and Skills. (2004). Every Child Matters: Change for Children. London: DfES.

Department for Education and Skills. (2005). Children's Workforce Strategy. A Strategy to build a world-class workforce for children and young people. London: DfES.

Department for Education and Skills. (2006). Children's Workforce Strategy: the Government's Response to the Consultation. London: DfES.

DUHN, I. (2006). The Making of Global Citizens: traces of cosmopolitanism in the New Zealand early childhood curriculum, Te Whāriki. Contemporary Issues in Early Childhood, 7(3), 191-202.

European Commission Network on Childcare and Other Measures to Reconcile Employment and Family Responsibilities. (1996). Quality Targets in Services for Young Children. Brussels.

FOUCAULT, M. (1972). The Archeology of Knowledge. New York: Pantheon.

FREIRE, P. (2000). Pedagogy of the oppressed (30th anniversary ed.). New York: Continuum.

FREIRE, P. (2004). Pedagogy of Hope. Reliving Pedagogy of the Oppressed. London: Continuum.

FREIRE, P., \& FREIRE, A. M. A. (1997). Pedagogy of the heart. New York: Continuum.

GADAMER, H.-G. (1960). Wahrheit und Methode : Grundzüge einer philosophischen Hermeneutik. Tübingen: Mohr.

GADAMER, H. G., WEINSHEIMER, J., \& MARSHALL, D. G. (2004). Truth and method (2nd, rev. ed. / translation revised by Joel Weinsheimer and Donald G. Marshall. ed.). London ; New York: Continuum.

GARRISON, J. (1996). A Deweyean theory of democratic listening. Educational Theory, 46(4), 429-451.

LARSON, M. S. (1977). The rise of professionalism: a sociological analysis. Berkeley: University of California Press.

MAC NAUGHTON, G. (2003). Shaping Early Childhood. Learners, Curriculum and Contexts. Berkshire: Open University Press.

MAC NAUGHTON, G. (2005). Doing Foucault in early childhood studies: applying poststructural ideas. London: Routledge.

MEAD, M. (1978). Culture and Commitment. The New relationships between the Generations in the 1970s. New York: Columbia University Press.

Ministry of Education. (2007). Centres of Innovation. http://www.minedu.govt.nz/index.cfm?layout=document\&documentid=10688\&indexid=8303\&indexparentid=10945 (Accessed 01/28/08).

MURRAY, C. (2006). The Conceptualisation of Diversity and Equality in Early Childhood Care and Education. Unpublished MSc thesis, University College Dublin, Dublin.

MURRAY, C., \& O'DOHERTY, A. (2001). Éist. Respecting Diversity in Early Childhood Care, Education and Training. Dublin: Pavee Point.

OBERHUEMER, P. (2005). Conceptualising the Early Childhood Pedagogue: Policy Approaches and Issues of Professionalism. European Early Childhood Education Research Journal, 13(1), 5-16.

OBERHUEMER, P., \& ULICH, M. (1997). Working with young children in Europe: provision and staff training. London: Paul Chapman.

OECD. (2001). Starting Strong. Early Childhood Education and Care. Paris: OECD.

OECD. (2004). OECD Thematic Review of Early Childhood Education and Care Policy in Ireland. Dublin: The Stationary Office.

OECD. (2006). Starting Strong II. Early Childhood Education and Care. Paris: OECD.

Office of the Minister for Children. (2006). Diversity and Equality Guidelines for Childcare Providers. Dublin: The Stationary Office.

OLIVER, M., \& CONOLE, G. (2003). Evidence-Based Practice in E-learning and Higher Education: can we and should we? Research Papers in Education, 18(4), 385-397.

PARSONS, T. (1951). The social system. Glencoe, Ill.,: Free Press.

PARSONS, T. (1968). Professions. In D. L. Sills \& R. K. Merton (Eds.), International encyclopaedia of the social sciences (Vol. 12, pp. 536-547). New York: Macmillan.

PEETERS, J. (2005). Flanders: Improving Inclusion Policies and Services. In Learning with other Countries: International Models of Early Education and Care (pp. 36-39). London: National Day Care Trust.

PENCE, A. R., \& MOSS, P. (1994). Valuing quality in early childhood services: new approaches to defining quality. London: P. Chapman.

PREISSING, C. (Ed.). (2003). Qualität im Situationsansatz : Qualitätskriterien und Materialien für die Qualitätsentwicklung in Kindertageseinrichtungen (1 ed.). Weinheim und Basel: Beltz.

RINALDI, C. (2005). In dialogue with Reggio Emilia: listening, researching, and learning. London; New York: Routledge.

SCHÖN, D. A. (1983). The Reflective Practitioner. How Professionals Think in Action. New York: Basic Books.

SCHWANDT, T. A. (2004). Hermeneutics: a Poetics of Inquiry Versus a Methodology for Research. In H. Piper \& I. Stronach (Eds.), Educational research: difference and diversity (pp. 31-44). Aldershot: Ashgate.

SIRAJ-BLATCHFORD, I., \& SYLVA, K. (2004). Researching pedagogy in English pre-schools. British Educational Research Journal, 30(5), 713-739.

SIRAJ-BLATCHFORD, I., SYLVA, K., \& MUTTOCK, S. (2002). Researching effective pedagogy in the early years: Great Britain, Department for Education and Skills.

TAYLOR, C. (1995). Philosophical arguments. Cambridge, Mass.: Harvard University Press.

TAYLOR, C. (2002). Gadamer on the human sciences. In R. J. Dostal (Ed.), The Cambridge Companion to Gadamer (pp. 126-142). Cambridge: Cambridge University Press. 
URBAN, M. (2003). From Standardized Quality towards 'Good Enough' Practice: a Dialogic Approach to Evaluation and Quality Development in Early Childhood Settings. Paper presented at the European Early Childhood Education Research Association (13th Annual Conference), University of Strathclyde, Glasgow.

URBAN, M. (2005a). Dealing with Uncertainty. Paper presented at the European Early Childhood Education Research Association (15th Annual Conference), St. Patrick's College, Dublin.

URBAN, M. (2005b). Quality, Autonomy and the Profession. In H. Schonfeld, S. O'Brien \& T. Walsh (Eds.), Questions of Quality. Dublin: Centre for Early Childhood Development and Education.

URBAN, M. (2006). Strategies for Change. Gesellschafts- und fachpolitische Strategien zur Reform des Systems frühkindlicher Bildung. Expertise für das Forum Frühkindliche Bildung der Bertelsmann Stiftung. Halle: Martin-Luther-Universität.

URBAN, M. (2007). Strategies for Change: Reflections from a Systemic, Comparative Research Project. In N. Hayes \& S. Bradley (Eds.), A Decade of Reflection. Early Childhood Care and Education in Ireland: 1996-2006 (pp. 44-64). Dublin: Centre for Social and Educational Research.

URBAN, M., HUHN, N., \& SCHAAF, M. (2004). Bildung:Elementar. Bildung als Programm für Kindertageseinrichtungen in Sachsen-Anhalt. Integrierter Abschlußbericht. Halle: Martin-Luther-Universität Halle-Wittenberg.

URBAN, M., \& MURRAY, C. (2005). Changing Habit(u)s. Perspectives on Change, Resistance and Professional Development. Paper presented at the International conference 'Honoring the child, honoring Equity 5: Reconsidering Rights and Relationship', Centre for Equity and Innovation in Early Childhood. University of Melbourne.

VANDENBROECK, M. (1999). The view of the Yeti. Bringing up children in the spirit of self-awareness and kindredship. The Hague: Bernard van Leer Foundation.

WINNICOTT, D. W. (1987). The Child, the Family and the Outside World. Cambridge: Perseus.

WOODHEAD, M. (1996). In Search of the Rainbow. Pathways to Quality in Large-Scale Programmes for Young Disadvantaged Children. The Hague: Bernhard van Leer Foundation.

Correspondence about this paper should be addressed to:

Dr. Mathias Urban

Martin-Luther-University Halle-Wittenberg

Faculty of Education

Franckeplatz 1, Haus 4

06110 Halle

GERMANY

Email: mathias.urban@paedagogik.uni-halle.de 